\title{
PENGEMBANGAN BIBIT UNGGUL PORANG (Amarphopallus oncophilus) MELALUI TEKNIK KULTUR IN VITRO UNTUK MENDUKUNG KETAHANAN PANGAN NASIONAL
}

\author{
Dwi Suheriyanto, Romaidi dan Ruri Siti Resmisari
}

Jurusan Biologi Fakultas Sains dan Teknologi Universitas Islam Negeri Maulana Malik Ibrahim Malang

Email: dsuheriyanto@yahoo.com

\begin{abstract}
Porang (Amarphophallus. oncophyllus) is a type of plant tubers that have the potential and prospects for development in Indonesia. In addition to readily available, plants are also capable of producing carbohydrates and high harvest index. The last few years a very large porang needs. Porang plant propagation is vegetative and generative in which to make the seeds are ready to harvest takes between 4-6 months. This study aims to determine kinds of the appropriate medium for growing plants porang network and determine the concentration of each medium, so we get a superior porang plants. Research using factorial completely randomized design. The first factor is a growth regulator BAP concentration: $0 \mathrm{mg} / \mathrm{l}, 0.5 \mathrm{mg} / \mathrm{l}, 1.0 \mathrm{mg} / \mathrm{l}, 1.5 \mathrm{mg} / \mathrm{l}$ and $2.0 \mathrm{mg} / \mathrm{l}$, while the second factor is the concentration of IBA $0 \mathrm{mg} / \mathrm{l}, 0.5 \mathrm{mg} / \mathrm{l}$ and $1.0 \mathrm{mg} / \mathrm{l}$, in order to obtain 15 treatments and each treatment made 15 replications. Data were collected for the pengkalusan, contamination callus, callus mortality rate, number of buds, leaf buds height, number of leaves and root. The results showed that the addition of plant growth regulators (hormones) BAP in MS medium effect on the number of shoots, buds and the high number of young leaves. The addition of hormone IBA in MS medium pengkalusan affect the process and the number of roots. The addition of hormone BAP and IBA on MS medium did not significantly affect mortality contamination callus and callus. The interaction between $B A P$ and IBA hormone given on MS medium did not significantly affect the pengkalusan, contamination callus, callus mortality rate, number of buds, leaf buds height, number of leaves and root

Keyword: Kata kunci: Porang, Amarphopallus oncophillus, benzyl amino purine (BAP), indole butyric acid (IBA)
\end{abstract}

\section{PENDAHULUAN}

Porang atau iles-iles (Amorphophallus muelleri Blume; sin. A. blumei (Scott.) Engler; sin. A. oncophyllus Prain) termasuk family Araceae, merupakan jenis tanaman umbi yang mempunyai potensi dan prospek untuk dikembangkan di Indonesia. Selain mudah didapatkan, tanaman ini juga mampu menghasilkan karbohidrat dan indeks panen tinggi. Dewasa ini kebutuhan makanan pokok utama berupa karbohidrat masih dipenuhi dari beras, diikuti jagung dan serealia yang lain. Sumber karbohidrat dari jenis umbi-umbian, seperti ubi kayu, ubi jalar, talas, kimpul, uwiuwian, ganyong, garut, suweg dan iles-iles pemanfaatannya belum optimal sehingga masih terbatas sebagai bahan makan alternatif di saat paceklik (Kriswidarti, 1980, 1981; Rijono, 1999).

Pada beberapa tahun terakhir kebutuhan porang sangat besar. Pada tahun 2009 kebutuhan chip porang mencapai 3.400 ton chip porang
(Wijanarko, 2009). Di Jawa Timur produksi porang pada tahun 2009 hanya sekitar 3.0005.000 ton umbi basah dan dengan rendemen $20 \%$, maka produksi chip masih sekitar $600 \mathrm{Kg}-1.000$ ton chip. Oleh karena itu, pada tahun 2010 Perum Perhutani Jawa Timur akan memperluas sampai 41.000 Ha. Kendala utama dalam percepatan produksi porang adalah lamanya waktu yang dibutuhkan untuk mencapai masa panen, menurut Sumarwoto (2005) waktu yang dibutuhkan untuk mencapai kondisi panen adalah 38-43 bulan.

Perbanyakan tanaman porang selama ini melalui dua metode yaitu secara vegetatif dengan menggunakan umbi batang, bagian umbi batang, umbi daun (bulbil) dan bagian daun. Sedangkan secara generatif melalui biji. Waktu yang dibutuhkan untuk menjadikan bibit siap panen membutuhkan waktu antara 4-6 bulan (Sumarwoto, 2005; Jansen et al. 1996; Ambarwati dkk., 2000). Berdasarkan pada kondisi diatas, maka perlu dilakukan penelitian mengenai alternatif perbanyakan lain, yang 
memungkinkan tanaman porang dikembangkan dalam waktu yang relatif singkat. Salah satu metode yang dapat digunakan adalah dengan teknik in vitro, metode ini memungkinkan perbanyakan dilakukan dalam waktu yang cepat dan jumlah yang banyak.

Penelitian bertujuan untuk mengetahui media apa saja yang sesuai untuk menumbuhkan jaringan tanaman porang dan mengetahui konsentrasi masing-masing media, sehingga didapatkan tanaman porang yang unggul.

\section{Bahan dan Metode}

Peralatan yang digunakan dalam penelitian ini adalah botol kultur, gelas erlenmeyer, gelas ukur, pipet, neraca, $\mathrm{pH}$-meter, autoklaf, oven, laminar air flow, hot plate, magnetic stirrer, kamera, Tally sheet serta alatalat lainnya. Sedangkan bahan tanaman (eksplan) yang digunakan yaitu tunas dari biji tumbuhan iles-iles yang sudah di subkultur, bahan kimia Media Murashige-Skoog dimodifikasi dan zat pengatur tumbuh. Penelitian menggunakan Rancangan Acak Lengkap Faktorial. Faktor pertama adalah zat pengatur tumbuh BAP dengan konsentrasi: $0 \mathrm{mg} / \mathrm{l}, 0,5 \mathrm{mg} / \mathrm{l}, 1,0 \mathrm{mg} / \mathrm{l}, 1,5 \mathrm{mg} / \mathrm{l}$ dan 2,0 mg/l sedangkan faktor kedua adalah IBA dengan konsentrasi $0 \mathrm{mg} / \mathrm{l}, 0,5 \mathrm{mg} / \mathrm{l}$ dan $1,0 \mathrm{mg} / \mathrm{l}$, sehingga diperoleh 15 perlakuan dan masingmasing perlakuan dibuat 15 ulangan.

Penelitian dimulai dengan menyiapkan eksplan dan kemudian kksplan tersebut dikeluarkan dan diletakan ke dalam cawan petridisk, lalu dipisahkan dari biji dengan memotongnya hingga batas mata tunas. Eksplan ditanam pada Media MS dengan penambahan perlakuan tunggal BAP $(0 ; 0,5 ; 1,0 ; 1,5 ; 2,0)$ $\mathrm{mg} / \mathrm{l}$, IBA $(0 ; 0,5 ; 1,0) \mathrm{mg} / \mathrm{l}$, dan kombinasi antar kedua perlakuan tersebut. Pengamatan dilakukan terhadap seluruh eksplan yang ditanam meliputi proses pengkalusan, kontaminasi, pencoklatan (browning), persentase tingkat kematian, jumlah tunas, tinggi kuncup daun, jumlah anak daun, serta jumlah akar pada eksplan porang.

Data yang diperoleh dianalisis menggunakan Analisis Varian (Anava) dua jalur. Bila terdapat perbedaan yang nyata antar perlakuan dilanjutkan dengan uji Duncan Multiple Range Test (DMRT) pada taraf 5\%. Pengolahan data dibantu dengan menggunakan sofware SPSS 15.0.

\section{Hasil dan Pembahasan}

Kalus merupakan sekumpulan massa sel yang belum terdiferensiasi menjadi organ dari tanaman. Kalus yang muncul merupakan hasil dari pembelahan sel-sel yang berada dalam jaringan eksplan. Hasil pengamatan menunjukkan bahwa persentase pengkalusan tertinggi dihasilkan dari perlakuan a3b3 (BAP $1 \mathrm{mg} / \mathrm{l}$ dan IBA $1 \mathrm{mg} / \mathrm{l}$ ), yaitu sebesar 6,67\%.

Stafford dan Graham (1991) menyatakan bahwa pembentukan kalus dari suatu tanaman terjadi dalam tiga tahap perkembangan yaitu:

1. Induksi sel (sel-sel siap melakukan pembelahan).

2. Pembelahan (sel-sel menjadi meristematik, lebih aktif membelah dan mengalami peningkatan ukuran sel).

3. Differensiasi (morfogenesis dan organogenesis) sel (sel mulai melebar dan membelah hingga tercapai keseimbangan antara pembelahan dan pelebaran).

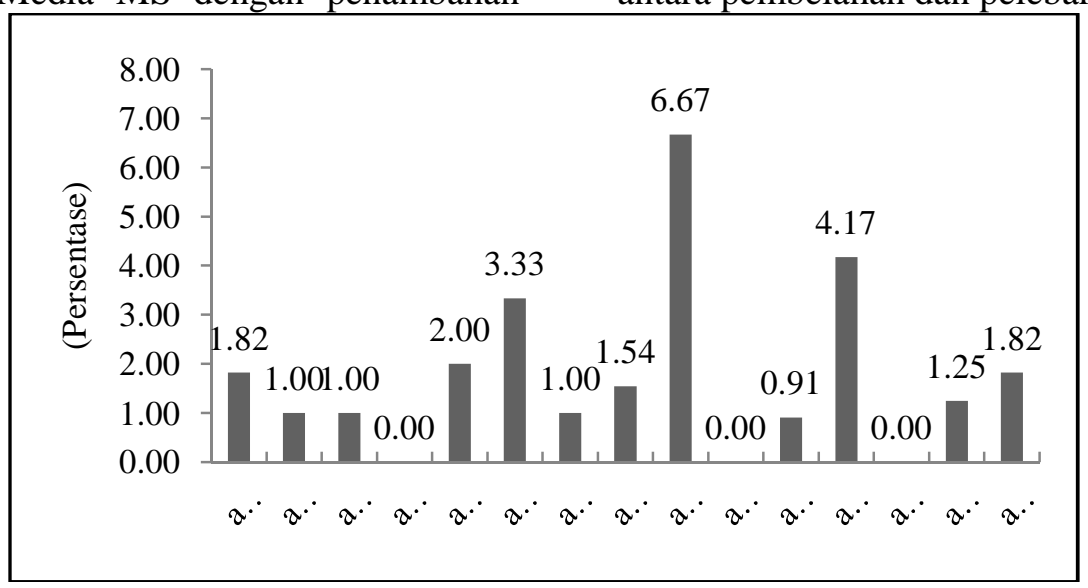

Gambar 4. Diagram batang persentase pengkalusan. a1: BAP $0 \mathrm{mg} / \mathrm{l}$, a2: BAP 0,5 mg/l, a3: BAP 1,0 $\mathrm{mg} / \mathrm{l}, \mathrm{a} 4:$ BAP 1,5 mg/l, a5: BAP 2,0 mg/l, b1: IBA 0 mg/l, b2: IBA 0,5 mg/l, b3: IBA 1,0 $\mathrm{mg} / \mathrm{l}$. 
Tabel 1. Pengaruh penambahan hormon IBA pada media MS terhadap persentase pengkalusan

\begin{tabular}{|c|c|}
\hline Perlakuan & Pengkalusan (\%) \\
\hline IBA $0 \quad \mathrm{mg} / \mathrm{l}$ & $0,84 \mathrm{a}$ \\
\hline IBA $0,5 \mathrm{mg} / 1$ & $0,91 \mathrm{a}$ \\
\hline IBA1,0 $\mathrm{mg} / \mathrm{l}$ & $1,18 \mathrm{~b}$ \\
\hline
\end{tabular}

Keterangan: angka yang di dampingi oleh huruf yang sama menunjukkan tidak berbeda nyata pada uji DMRT 5\%

Berdasarkan hasil analisis varian diketahui bahwa hanya perlakuan IBA yang memberikankan pengaruh nyata terhadap persentase pengkalusan. Pemberian hormon IBA sebanyak $1 \mathrm{mg} / \mathrm{l}$ pada media MS memberikan pengaruh yang nyata dibandingkan perlakuan lainnya. Pada perlakuan IBA $1 \mathrm{mg} / \mathrm{l}$ mampu menghasilkan kalus $1,18 \%$ (tabel 1.). Bhojwani dan Razdan (1996) menyatakan bahwa auksin
(IBA) pada umumnya merangsang pertumbuhan kalus.

Menurut Hendaryono dan Wijayani (1994), IBA dapat meningkatkan tekanan osmotik, sintesis protein dan permeabilitas sel terhadap air. Hal ini menyebabkan air dapat masuk ke dalama sel, sehingga volume kalus meningkat. Dengan adanya peningkatan sintesis protein, maka dapat digunakan sebagai sumber tenaga dalam pertumbuhan.

Berdasarkan hasil analisis varian diketahui bahwa tidak ada pengaruh yang nyata dari pemberian hormon IBA, BAP maupun interaksi antara pemberian hormon IBA dan BAP terhadap kontaminasi pertumbuhan kalus porang. Pada gambar 5. dapat dilihat bahwa kontaminasi tertinggi mencapai $46,67 \%$, namun persentase kontaminasi tersebut secara statistik tidak berbeda nyata dengan semua perlakuan.

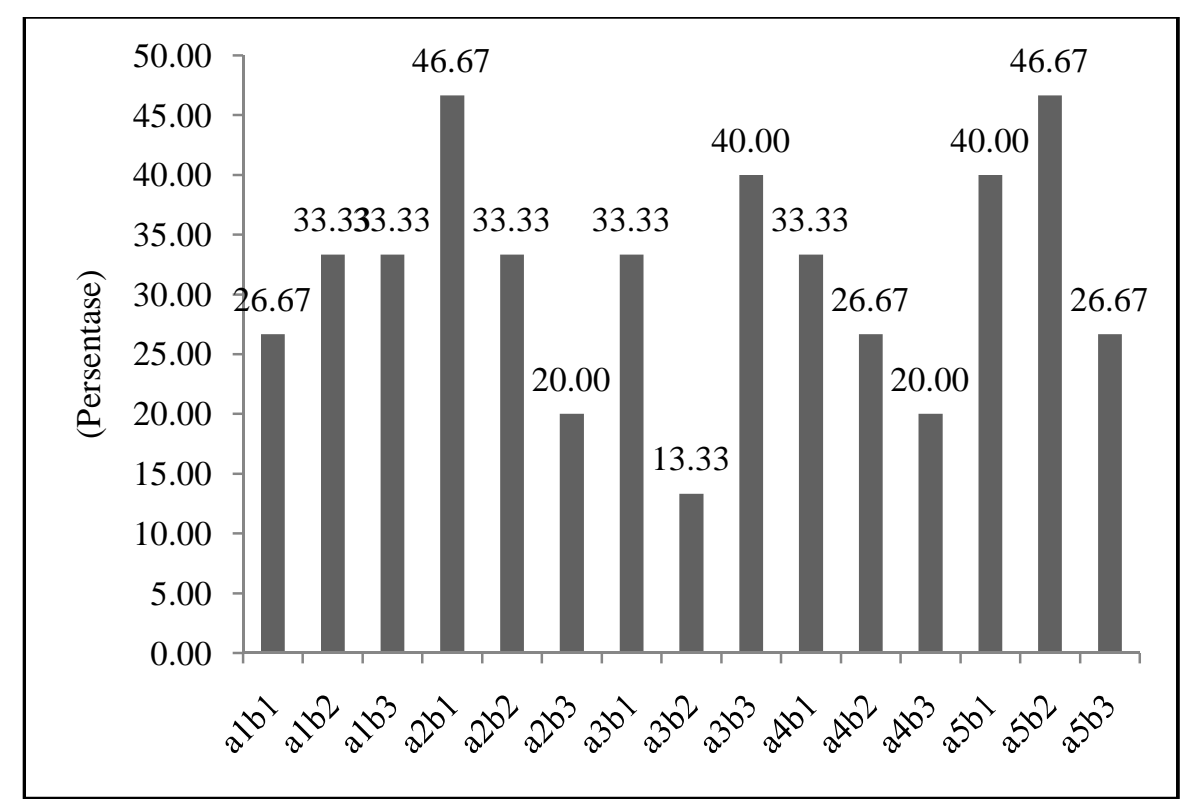

Gambar 5. Diagram batang kontaminasi kalus. a1: BAP $0 \mathrm{mg} / \mathrm{l}$, a2: BAP 0,5 mg/l, a3: BAP 1,0 mg/l, a4: BAP 1,5 mg/l, a5: BAP 2,0 mg/l, b1: IBA 0 mg/l, b2: IBA 0,5 mg/l, b3: IBA 1,0 mg/l.

Kontaminasi yang terjadi dapat disebabkan oleh lingkungan kerja, media tanam atau bahan tanam yang sterilisasinya kurang sempurna. Sterilisasi yang kurang sempurna ini mengakibatkan tumbuhnya mikroorganisme pada media yang sangat kaya akan nutrisi. 


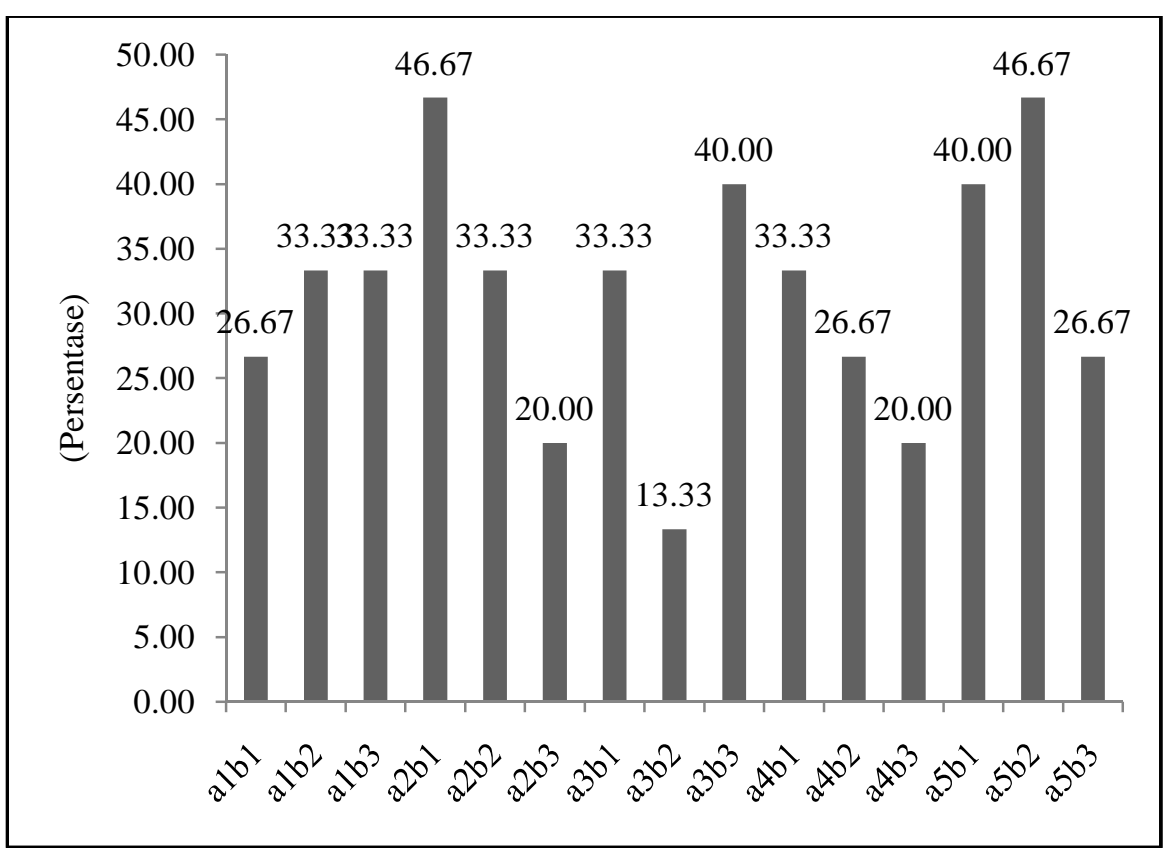

Gambar 6. Diagram batang tingkat kematian kalus. a1: BAP $0 \mathrm{mg} / \mathrm{l}$, a2: BAP 0,5 mg/l, a3: BAP 1,0 $\mathrm{mg} / \mathrm{l}$, a4: BAP 1,5 mg/l, a5: BAP 2,0 mg/l, b1: IBA 0 mg/l, b2: IBA 0,5 mg/l, b3: IBA 1,0 $\mathrm{mg} / \mathrm{l}$.

Tingkat kematian kalus porang berdasarkan analisis varian menunjukkan tidak berbeda nyata antara pemberian hormon IBA, BAP maupun interaksi perlakuan antara pemberian hormon IBA dan BAP.

Kematian yang terjadi pada penelitian ini kemungkinan disebabkan oleh adanya kontaminasi dari mikroorganisme, baik oleh jamur ataupun bakteri. Kontaminasi ini dikarenakan media MS merupakan media yang kaya akan nutrisi, sehingga mikroorganisme di sekitar kalus tumbuh dan berkompetisi dengan kalus. Pada akhirnya kalus yang sudah terbentuk pertumbuhannya tidak sempurna dan mengalami kematian.

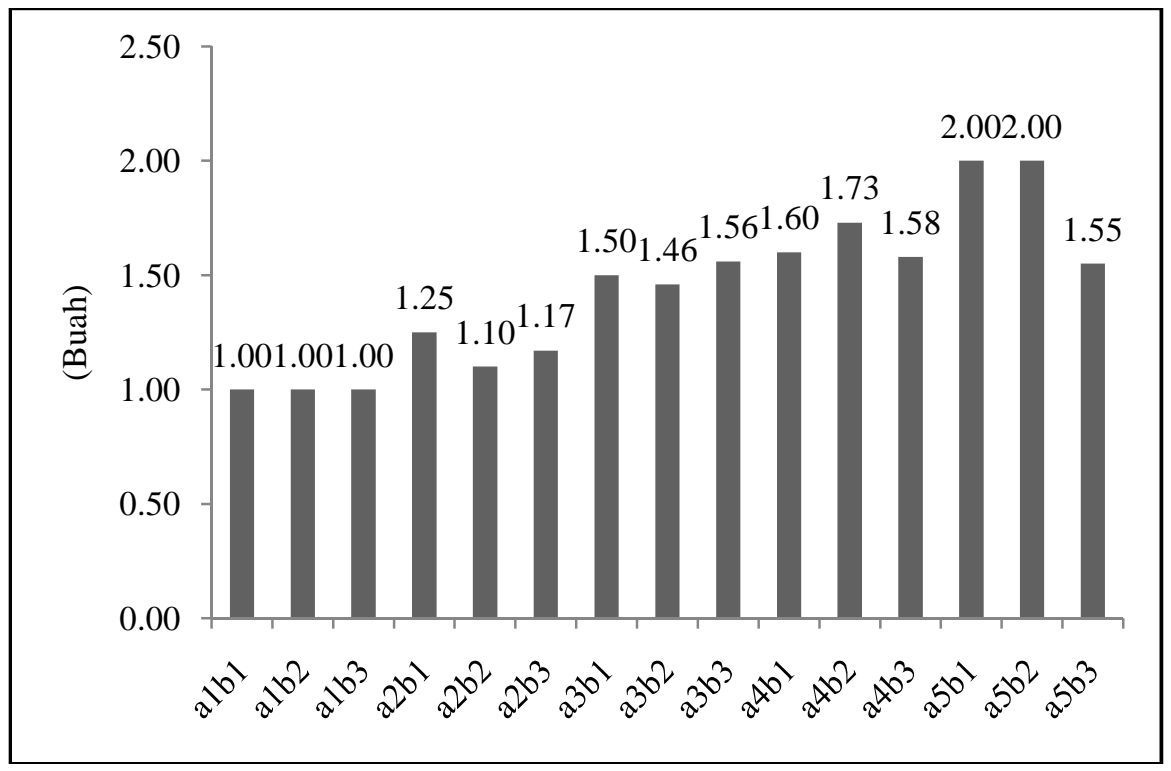

Gambar 7. Diagram batang jumlah tunas. a1: BAP $0 \mathrm{mg} / \mathrm{l}$, a2: BAP 0,5 mg/l, a3: BAP 1,0 mg/l, a4: BAP 1,5 mg/l, a5: BAP 2,0 mg/l, b1: IBA 0 mg/l, b2: IBA 0,5 mg/l, b3: IBA 1,0 mg/l. 
Tabel 2. Pengaruh penambahan hormon BAP pada media MS terhadap jumlah tunas

\begin{tabular}{|c|c|}
\hline Perlakuan & Jumlah tunas (buah) \\
\hline BAP $0 \mathrm{mg} / \mathrm{l}$ & $1,06 \quad \mathrm{a}$ \\
\hline BAP $0,5 \mathrm{mg} / \mathrm{l}$ & $1,09 \mathrm{ab}$ \\
\hline BAP $1,0 \mathrm{mg} / \mathrm{l}$ & $1,20 \mathrm{ab}$ \\
\hline BAP $1,5 \mathrm{mg} / \mathrm{l}$ & $1,25 \quad b$ \\
\hline BAP 2,0 mg/l & $1,22 \mathrm{ab}$ \\
\hline
\end{tabular}

Keterangan: angka yang di dampingi oleh huruf yang sama menunjukkan tidak berbeda nyata pada uji DMRT 5\%

Pemberian hormon BAP yang paling berpotensi untuk menumbuhkan tunas pada media kultur porang. Pembentukan tunas dari kalus akibat dari pengaruh hormon BAP yang diberikan pada media MS. BAP merupakan senyawa kelompok sitokinin yang memacu pembelahan sel, sehingga mampu memacu pembentukan kalus atau massa sel. Kalus yang terbentuk dapat dipacu untuk berdiferensiasi menjadi tunas.

Menurut Gunawan (1995), penggunaan BAP dalam konsentrasi yang tinggi dan masa induksi yang panjang dapat menentukan kemampuan pembentukan jumlah tunas dan bentuk tunas. Berdasarkan tabel 2. dapat diketahui bahwa, perlakuan dengan hormon BAP $1,5 \mathrm{mg} / \mathrm{l}$ menunjukkan berbeda nyata dengan kontrol, tetapi tidak berbeda nyata dengan perlakuan yang lain. Hal ini berarti bahwa pemberian hormon BAP berpengaruh terhadap banyaknya tunas yang dihasilkan pada kultur porang.

Berdasarkan hasil analisis varian dapat diketahui bahwa penambahan hormon BAP pada media MS berpengaruh nyata terhadap tinggi kuncup daun porang, sedangkan perlakuan dengan hormon IBA dan kombinasi IBA dan BAP menunjukkan tidak berbeda nyata.

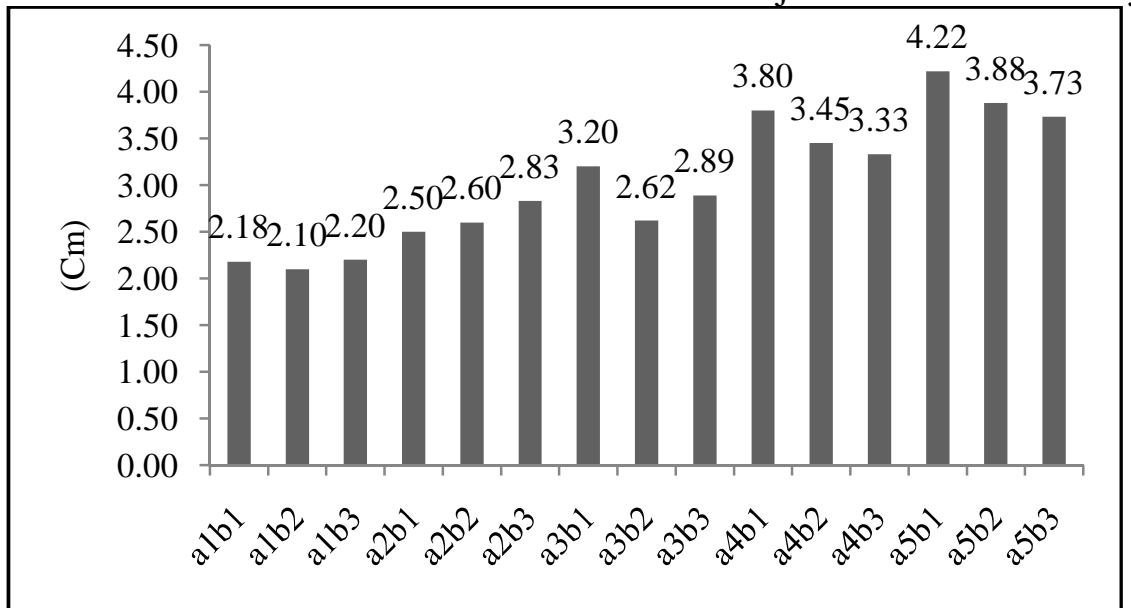

Gambar 8. Diagram batang tinggi kuncup daun. a1: BAP $0 \mathrm{mg} / \mathrm{l}$, a2: BAP 0,5 mg/l, a3: BAP 1,0 mg/l, a4: BAP 1,5 mg/l, a5: BAP 2,0 mg/l, b1: IBA 0 mg/l, b2: IBA 0,5 mg/l, b3: IBA 1,0 mg/l.

BAP dengan konsentrasi yang tepat dibutuhkan dalam perpanjangan tunas pada kultur jaringan. Konsentrasi BAP yang terlalu tinggi akan merusak jaringan, sehingga pertumbuhan dan pembentukan buku tunas berkurang serta menghambat pembesaran sel.

Tabel 3. Pengaruh penambahan hormon BAP pada media MS terhadap tinggi kuncup daun

\begin{tabular}{|c|c|}
\hline Perlakuan & Tinggi kuncup $(\mathrm{cm})$ \\
\hline BAP 0 $\mathrm{mg} / \mathrm{l}$ & $1,34 \quad \mathrm{a}$ \\
\hline BAP $0,5 \mathrm{mg} / 1$ & $1,43 \mathrm{ab}$ \\
\hline BAP $1,0 \mathrm{mg} / \mathrm{l}$ & $1,53 \mathrm{ab}$ \\
\hline BAP $1,5 \mathrm{mg} / \mathrm{l}$ & $1,65 \mathrm{~b}$ \\
\hline BAP $2,0 \mathrm{mg} / \mathrm{l}$ & $1,56 \mathrm{ab}$ \\
\hline
\end{tabular}

Keterangan: angka yang di dampingi oleh huruf yang sama menunjukkan tidak berbeda nyata pada uji DMRT 5\%

Tinggi kuncup daun porang pada perlakuan hormon BAP $1,5 \mathrm{mg} / \mathrm{l}$ menunjukkan berbeda nyata dengan kontrol, namun tidak berbeda nyata dengan perlakuan lain (tabel 3.). Hal ini menunjukkan bahwa penambahan hormon BAP sebesar 1,5 $\mathrm{mg} / \mathrm{l}$ pada media MS berpengaruh nyata terhadap tinggi kuncup daun pada kultur porang. 


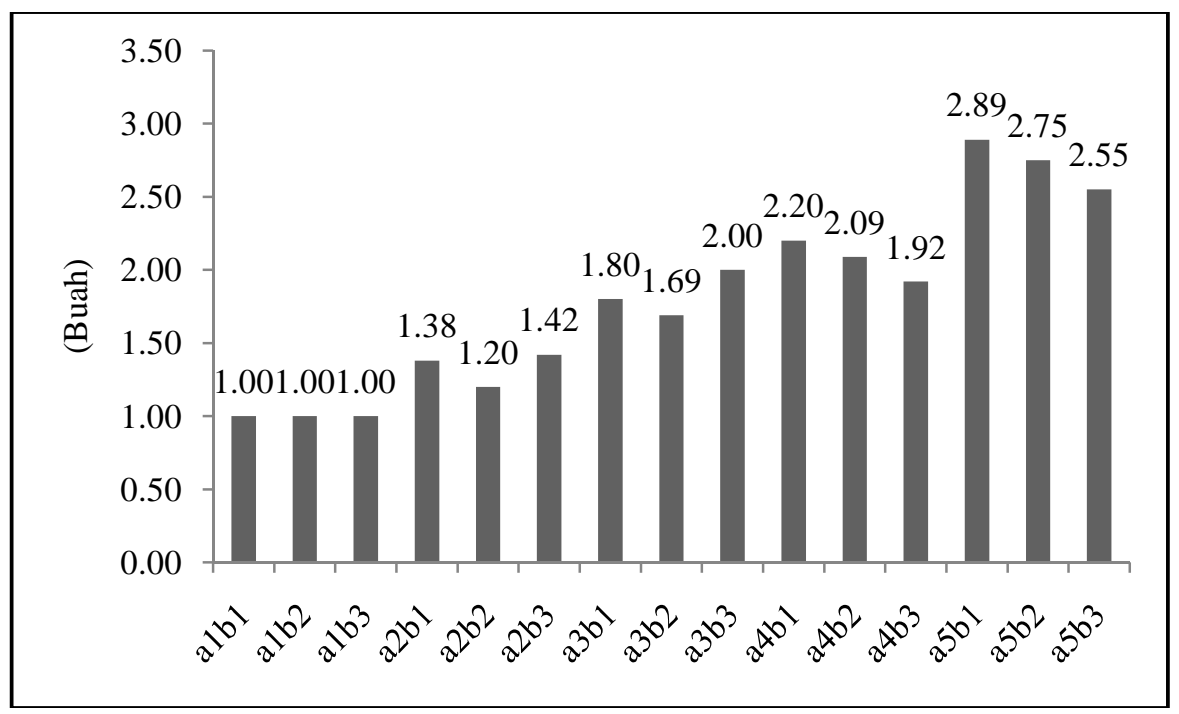

Gambar 9. Diagram batang jumlah anak daun. a1: BAP 0 mg/l, a2: BAP 0,5 mg/l, a3: BAP 1,0 mg/l, a4: BAP 1,5 mg/l, a5: BAP 2,0 mg/l, b1: IBA 0 mg/l, b2: IBA 0,5 mg/l, b3: IBA 1,0 mg/l.

Tabel 4. Pengaruh penambahan hormon BAP pada media MS terhadap jumlah anak daun

\begin{tabular}{|c|c|}
\hline Perlakuan & Jumlah anak daun (buah) \\
\hline BAP $0 \quad \mathrm{mg} / \mathrm{l}$ & 1,06 a \\
\hline BAP $0,5 \mathrm{mg} / \mathrm{l}$ & $1,13 \mathrm{ab}$ \\
\hline BAP $1,0 \mathrm{mg} / \mathrm{l}$ & $1,28 \mathrm{bc}$ \\
\hline BAP $1,5 \mathrm{mg} / \mathrm{l}$ & $1,34 \mathrm{c}$ \\
\hline BAP 2,0 mg/l & $1,39 \mathrm{c}$ \\
\hline
\end{tabular}

Keterangan: angka yang di dampingi oleh huruf yang sama menunjukkan tidak berbeda nyata pada uji DMRT 5\%

Berdasarkan tabel 4 dapat diketahi bahwa penambahan hormon BAP sebesar $1,0 \mathrm{mg} / \mathrm{l}, 1,5$ $\mathrm{mg} / \mathrm{l}$ dan 2,0 mg/l pada media MS menunjukkan berbeda nyata dengan kontrol. Hal ini berarti bahwa penambahan hormon BAP mulai konsentrasi $1,0 \mathrm{mg} / \mathrm{l}$ memberikan pengaruh yang nyata terhadap jumlah anak daun pada kultur porang. Jumlah anak daun yang terbentuk semakin meningkat seiring dengan peningkatan konsentrasi BAP yang diberikan. Jumlah anak daun tertinggi diperoleh pada penambahan BAP 2,0 mg/l, yaitu sebanyak 1,39 buah.

Jumlah anak daun yang dihasilkan berhubungan dengan fungsi BAP dalam mendorong pembelahan sel dan proses organogenesis dalam proses mikropropagasi. BAP sangat berperan dalam pembentukan dan penggandaan tunas in vitro. George dan Sherrrington (1984) menyatakan bahwa BAP merupakan zat pengatur tumbuh yang sangat efektif dalam menginduksi proliferasi tunas in vitro.

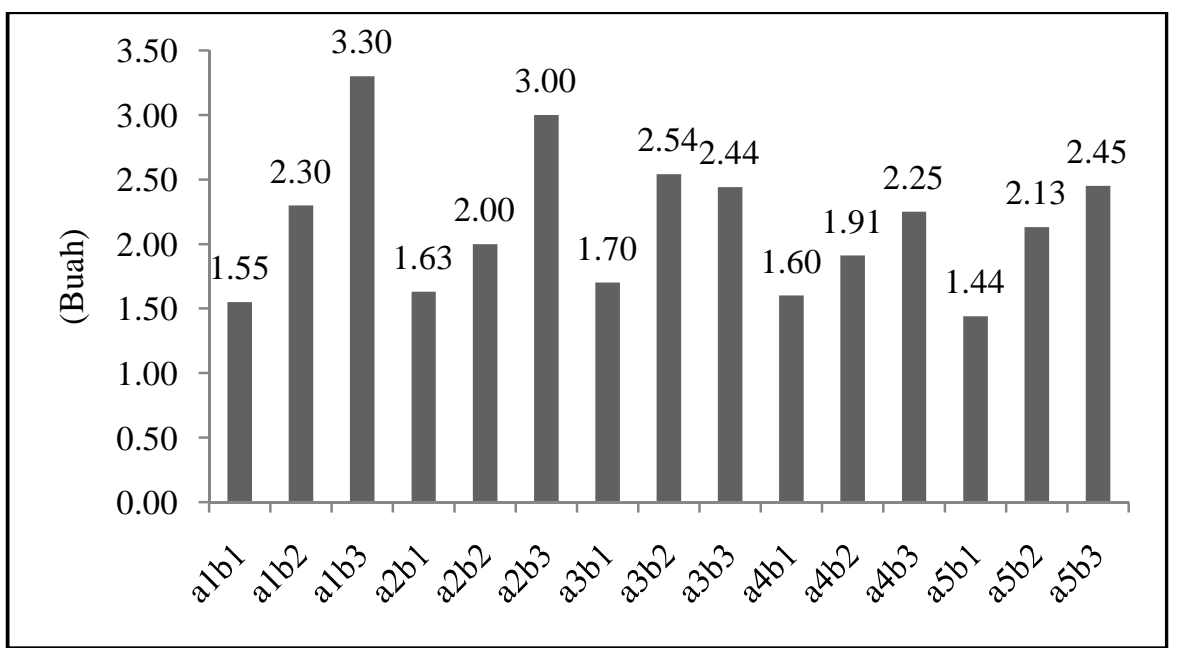

Gambar 10. Diagram batang jumlah akar. a1: BAP 0 mg/l, a2: BAP 0,5 mg/l, a3: BAP 1,0 mg/l, a4: BAP 1,5 mg/l, a5: BAP 2,0 mg/l, b1: IBA 0 mg/l, b2: IBA 0,5 mg/l, b3: IBA 1,0 mg/l. 
Analisis varian terhadap jumlah akar menunjukkan bahwa pemberian hormon IBA pada media MS berpengaruh nyata terhadap jumlah akar. Penambahan hormon IBA pada media MS sebesar $1,0 \mathrm{mg} / \mathrm{l}$ berbeda nyata dengan kontrol (tabel 5.). Hal ini menunjukkan bahwa penambahan hormon IBA berpengaruh nyata terhadap jumlah akar yang dihasilkan pada kultur porang. IBA merupakan pemicu pertumbuhan akar, yang berperan dalam pembentukan akar dan perpanjangan sel.

Tabel 5. Pengaruh penambahan hormon IBA pada media MS terhadap jumlah akar

\begin{tabular}{lrl}
\hline \multicolumn{2}{c}{ Perlakuan } & Jumlah akar (buah) \\
\hline IBA 0 & $\mathrm{mg} / \mathrm{l}$ & $1,18 \mathrm{a}$ \\
IBA 0,5 & $\mathrm{mg} / \mathrm{l}$ & $1,32 \mathrm{a}$ \\
IBA 1,0 & $\mathrm{mg} / \mathrm{l}$ & $1,48 \quad \mathrm{~b}$ \\
\hline
\end{tabular}

Keterangan: angka yang di dampingi oleh huruf yang sama menunjukkan tidak berbeda nyata pada uji DMRT 5\%

IBA sangat dikenal sebagai senyawa yang mampu berperan menginduksi terjadinya kalus, mendorong proses morfogenesis kalus, membentuk akar atau tunas, mendorong proses embryogenesis dan dapat mempengaruhi kestabilan genetik sel tanaman (Santoso dan Nursandi, 2003). Abidin (1983) menambahkan bahwa IBA mempunyai aktifitas sebagai hormon akar, sehingga aktifitas IBA dapat berpengaruh terhadap jumlah akar.

\section{Kesimpulan}

Kultur jaringan tanaman porang dapat dilakukan dengan menggunakan media MS yang ditambah hormon tunggal BAP dan IBA. Tanaman porang yang unggul dapat dihasilkan dari kultur jaringan dengan menggunakan media MS yang ditambah hormon BAP $1,5 \mathrm{mg} / \mathrm{l}$ untuk meningkatkan jumlah tunas, tinggi kuncup daun dan jumlah anak daun serta hormon IBA $1,0 \mathrm{mg} / \mathrm{l}$ untuk merangsang pengkalusan dan jumlah akar. Penambahan hormon BAP dan IBA pada media MS tidak pengaruh nyata terhadap kontaminasi kalus dan tingkat kematian kalus. Interaksi antara hormon BAP dan IBA yang diberikan pada media MS tidak berpengaruh nyata terhadap proses pengkalusan, kontaminasi kalus, tingkat kematian kalus, jumlah tunas, tinggi kuncup daun, jumlah anak daun dan jumlah akar.

\section{Ucapan Terima Kasih}

Penulis mengucapkan terima kasih kepada Direktorat Pendidikan Tinggi Islam, Direktorat Jenderal Pendidikan Islam, Kementerian Agama RI yang telah memberikan Bantuan Dana Penelitian Kompetitif Tahun 2010.

\section{Daftar Pustaka}

Abidin, Z. 1985. Dasar-dasar Pengetahuan Tentang Zat Pengatur Tumbuh. Bandung: Penerbit Angkasa.

Ambarwati, E., R.H. Murti, Haryadi, A. Basyir, dan S. Widodo. 2000. Eksplorasi dan Karakterisasi Iles-iles. Yogyakarta: LP UGM Bekerjasama dengan BPPTPPP/ PAATP Balitbangtan.

Bhojwani, S. S and M. K. Razdan, 1996. Plant Tissue Culture : Theory and Practice, a Revised Edition. Elsevier Science. Amsterdam. The Netherlands.

George. E.F., and Sherrington .P.D. 1984. Plant Propagation by Tissue Cultur. Hand book and directory of Comersial Laboratorie. Exegetics Limited. England

Gunawan, L. W. 1995. Teknik Kultur Jaringan. Bogor. Laboratorium Kultur Jaringan Tanaman: PAU IPB.

Jansen, P.C.M., C. van der Wilk, and W.L.A. Hetterscheid. 1996. Amorphophallus Blume ex Decaisne. In Flach, M. and F. Rumawas (eds.). PROSEA: Plant Resources of South-East Asia No 9. Plant Yielding Non-seed Carbohydrates. Leiden: Backhuys Publishers.

Hendaryono, D. P. S dan Wijayani, A. 1994. Teknik Kultur Jaringan: Pengenalan dan Petunjuk Perbanyakan Tanaman Secara Vegetatif Modern. Yogyakarta: Kanisius.

Kriswidarti, T. 1980. Suweg (Amorphophallus campanulatus $\mathrm{Bl}$ ) kerabat bunga bangkai yang berpotensi sebagai sumber karbohidrat. Buletin Kebun Raya 4 (5).

Kriswidarti, T. 1981. Pengamatan morfologi jenis-jenis Amorphophallus di Jawa. Dalam: Penelitian Peningkatan Pendayagunaan Sumberdaya Hayati. [Laporan Teknik 1981-1982]. Bogor: Lembaga Biologi Nasional, LIPI. 
Rijono. 1999. Buku Pengelolaan Tanaman Ilesiles (Amorphophallus onchophyllus). Madiun: Perum Perhutani KPH Saradan, Madiun, Jawa Timur.

Santoso, U dan Nursandi, F. 2003. Kultur Jaringan Tanaman. Malang: Pusbitan UMM.

Stafford, A. and Graham, W. 1991. Plant Cell And Tissue Culture. Dapertement of Moleculer Biology and Biotecnology University of Sheffield, UK.

Sumarwoto, 2005. Iles-iles (Amorphophallus muelleri Blume); Deskripsi dan Sifatsifat Lainnya. Biodiversitas. Volume 6 , Nomor 3.

Wijanarko, 2009. Prospek Pengembangan Porang di Kawasan Hutan Jawa Timur. http://simonbwidjanarko.wordpress.c om Tanggal Akses 11 April 2010.

Yusnita. 2003. Kultur Jaringan: Cara Memperbanyak Tanaman Secara Efisien. Jakarta: PT Agromedia Pustaka. 